\title{
PENGEMBANGAN MEDIA PEMBELAJARAN E-LEARNING BERBASIS MOODLE PADA MATERI PECAHAN SENILAI KELAS IV SEKOLAH DASAR
}

\author{
Meisya Widyasusanti ${ }^{1 *}$, Iva Sarifah ${ }^{2},{\text { Herlina } \text { Usman }^{3}}^{3}$ \\ ${ }^{1,2,3}$ Universitas Negeri Jakarta, Indonesia \\ *Corresponding Author: @ meisya.widya14@gmail.com
}

\begin{abstract}
Info Artikel
Sejarah Artikel:

Diterima: $11 / 10 / 2021$

Direvisi: $15 / 10 / 2021$

Disetujui:20/10/2021

Keywords:

Moodle, fractions, math

$4^{\text {th }}$ graders.

Kata Kunci:

Moodle, pecahan senilai, matematika, Kelas 4 SD

Abstract. This research and development produced a market-tested media and is suitable to be used by educators. This education media help students in their learning process whilst still having fun, especially in the topic of fractions. This research and development was built using the ASSURE model and adopted the evaluation process by Dick and Carey. The subjects of this RnD are the students from SDN Ragunan 01 Jakarta Selatan's 4 th grade class, with a total of 18 students. Data collection was done through interviews and questionnaires and with Miles and Huberman data anlysis. Results of the research show that e-learning on Moodle is a learning media worth using, in this case for the purpose of teaching fractions to 4 th graders. The results show an impressive expert review average score of $87.2 \%$ by the subjects in their understanding of the lesson. This media received positive response from the 3 selected students during the one to one tryout stage and a $96.42 \%$ mark by the subjects during the field trial stage. It is evident that this moodle-based e-learning media is properly made, well tested, and suitable for use in the education field - specifically for the purpose of teaching fractions to 4th graders.
\end{abstract}

Abstrak. Penelitian dan pengembangan ini bertujuan untuk menghasilkan sebuah media yang sudah teruji dan layak digunakan oleh pendidik sebagai media pembelajaran yang akan membantu peserta didik lebih mudah dalam memahami materi pecahan senilai dan dapat membuat peserta didik lebih antusias untuk mengikuti proses pembelajaran. Penelitian dan pengembangan ini menggunakan model ASSURE dan mengadaptasi proses evaluasi formatif dari Dick and Carey. Responden dalam penelitian ini adalah siswa kelas IV SDN Ragunan 01 Jakarta Selatan sebanyak 18 orang. Pengumpulan data dilakukan dengan wawancara dan kuesioner, serta menggunakan analisis data Miles and Huberman. Hasil penelitian menunjukkan bahwa media pembelajaran e-learning berbasis moodle pada matematika materi pecahan senilai kelas IV SD layak dijadikan sebagai salah satu media untuk mempelajari pecahan senilai dalam matematika kelas IV SD dengan perolehan rata-rata skor pada tahap expert review sebesar 87,2\% yang berarti sangat layak. Pada tahap one to one tryouts media ini mendapat respon positif dari ketiga orang siswa yang diwawancara dan pada tahap field trials memperoleh rata-rata skor sebesar 96,42\% yang berarti sangat layak. Oleh sebab itu, media pembelajaran e-learning berbasis moodle dapat digunakan sebagai media penunjang dalam mempelajari materi pecahan senilai dalam matematika untuk kelas IV SD.

How to Cite: Widyasusanti,M., Sarifah,I., \& Usman, H. (2022). PENGEMBANGAN MEDIA PEMBELAJARAN E-LEARNING BERBASIS MOODLE PADA MATERI PECAHAN SENILAI KELAS IV SEKOLAH DASAR. Prima Magistra: Jurnal Ilmiah Kependidikan, 3(1), 1-15. https://doi.org/10.37478/jpm.v3i1.1289

\section{Alamat korespondensi:}

Jl. Taman Setia Budi I No.2, RW.2, Kuningan, Kecamatan Setiabudi, Kota Jakarta Selatan, Daerah Khusus Ibukota Jakarta 12910. meisya.widya14@gmail.com
Penerbit:

Program Studi PGSD Universitas Flores.

@) primagistrauniflor@gmail.com 


\section{PENDAHULUAN}

Matematika merupakan suatu ilmu abstrak yang berkaitan dengan logik, pola pikir, konsep, dan operasi yang memiliki hubungan dengan suatu bilangan. Matematika yang termasuk dalam cabang ilmu pengetahuan memiliki peranan yang penting di sekolah maupun dalam kehidupan sehari-hari (Purnomo, 2018). Sebagai salah satu mata pelajaran, matematika memegang peranan yang sangat penting dalam dunia pendidikan karena selain dapat mengembangkan berbagai penalaran yang logis, rasional, dan kritis matematika juga memberikan keterampilan kepada peserta didik untuk memecahkan berbagai masalah dalam kehidupan sehari-hari maupun dalam mempelajari ilmu lainnya.

Salah satu tujuan pembelajaran matematika adalah peserta didik memiliki kemampuan berpikir secara logis, kritis, analitis, kreatif, sistematis, dan bekerja sama (Syadiyah \& Huda, 2020). Selain itu, pembelajaran matematika harus dapat mempermudah peserta didik dalam memahami sesuatu, meningkatkan keterampilan yang dimiliki oleh peserta didik, serta membantu meningkatkan sikap positif peserta didik terhadap mata pelajaran matematika. Agar tujuan tersebut dapat terwujud, proses pembelajaran matematika di sekolah dasar hendaknya menggunakan media yang dapat menunjang proses pembelajaran.

Penggunaan media yang tepat untuk peserta didik sekolah dasar dalam proses pembelajaran matematika salah satunya adalah dengan menggunakan media konkrit (Kristiani \& Prasetyo, 2016). Hal ini sejalan dengan teori perkembangan kognitif Jean Piaget, dimana anak yang berusia 7-12 tahun berada di dalam tahap perkembangan operasional konkrit, dan sudah memiliki kemampuan dalam berpikir secara logis, namun hanya dengan bendabenda yang bersifat konkrit (Adnan, Juriana, Lestari, \& Novianti, 2016).

Semenjak munculnya COVID-19, dunia pendidikan menjadi salah satu bidang yang terkena dampak dari pandemik COVID19. Kegiatan pembelajaran yang sebelumnya dilakukan di sekolah, kini dilakukan di rumah melalui daring dalam rangka pencegahan penyebaran COVID-19. Hal ini tercantum dalam Surat Edaran Nomor 4 Tahun 2020 pada Satuan Pendidikan dan Nomor 36962/MPK.A/HK/2020 tentang Pelaksanaan Pendidikan dalam Masa Darurat Coronavirus Disease (COVID-19) (Anonim, 2020). Berbagai jenis media pembelajaran berbasis teknologi informasi dan komunikasi dijadikan sebagai media penunjang dalam proses pembelajaran matematika, seperti WhatsApp, Google Meet, Zoom, maupun e-learning seperti Google Classroom. Namun dalam pelaksanaannya, tidak semua media tersebut dapat diterapkan secara merata di sekolah (Muhammad, 2020). Hal ini bergantung pada faktor lingkungan dan karakteristik peserta didik.

Faktor lingkungan seperti kurangnya sarana dan prasarana, serta suasana yang tidak mendukung peserta didik untuk belajar matematika secara daring. Selain itu, ketersediaan media pembelajaran konkrit yang kurang untuk membantu peserta didik dalam mempelajari ilmu matematika yang abstrak. Peserta didik pun kesulitan dalam mempelajari matematika, terutama karena peserta didik harus berimajinasi dalam mempelajari matematika karena kurangnya media pembelajaran konkrit. Melalui penggunaan media konkrit di sekolah dasar, peserta didik dapat melihat secara langsung benda yang digunakan sebagai media tanpa berimajinasi. Peserta didik akan lebih banyak belajar dibanding sekedar berimajinasi dan lebih mudah memahami konsep yang abstrak dalam matematika.

Kemudahan untuk memahami konsep matematika yang abstrak oleh peserta didik diperkuat oleh hasil penelitian yang dilakukan oleh Kimin (2020) yang berhasil membuktikan bahwa penggunaan peraga benda konkrit dapat meningkatkan hasil belajar siswa pada Pelajaran Matematika khususnya Penjumlahan Pecahan di kelas II SDN Tuban. Hal ini ditunjukkan melalui hasil penelitian tindakan kelas (PTK) yang dilakukan sebanyak dua siklus, dimana pada siklus pertama peserta didik yang mencapai nilai ketuntasan sebanyak $63 \%$ dan pada siklus kedua, jumlah peserta didik yang mencapai nilai ketuntasan sebanyak 95\%, 
sehingga terjadi peningkatan sebesar 32,25 poin (Kimin, 2020).

Jika proses pembelajaran matematika secara daring masih berlangsung menggunakan media yang belum sesuai dengan faktor lingkungan dan karakteristik peserta didik, maka akan memberi beberapa pengaruh buruk terhadap peserta didik dalam mempelajari matematika. Beberapa kemungkinan buruk tersebut antara lain, peserta didik kurang tertarik pada pelajaran, kurangnya motivasi peserta didik dalam mempelajari matematika, dan peserta didik tidak mampu memahami materi yang diajarkan dalam matematika.

Salah satu materi matematika di kelas IV yang dalam proses pembelajarannya harus dibantu dengan menggunakan media konkrit adalah pecahan senilai. Pada pembelajaran materi pecahan senilai, kesalahan yang sering ditemukan adalah anggapan peserta didik bahwa $\frac{a}{b}$ tidak sama

nilainya dengan $\frac{m a}{m b}$. Hal ini dikarenakan

peserta didik hanya melihat dari perbedaan bilangan yang terdapat pada pembilang dan penyebut pada pecahan tersebut dan kurangnya pemahaman konsep pecahan senilai dari media konkrit, sehingga menganggap kedua pecahan tidak senilai.

Berdasarkan observasi mengenai pelaksanaan pembelajaran matematika kelas IV pada tanggal 1 September 2020 di sebuah Sekolah Dasar Negeri di daerah Jakarta Selatan, diperoleh informasi bahwa sekolah tersebut menggunakan whatsapp dan google classroom dalam melaksanakan kegiatan pembelajaran selama pandemik COVID-19. Ditemukan pula informasi tentang berbagai keterbatasan lainnya dalam proses belajar matematika selama pandemik COVID-19.

Keterbatasan - keterbatasan itu diantaranya adalah: pertama, pendidik mengalami kesulitan dalam menyampaikan pembelajaran matematika materi pecahan senilai tanpa media konkrit yang mendukung secara daring; kedua, pendidik tidak dapat memantau peserta didik dalam pembelajaran secara real time.

$\begin{array}{lll}\text { Berdasarkan } & \text { hasil } & \text { wawancara } \\ \text { dengan Wali Kelas IV pada } & \text { tanggal } 8 \\ \text { November 2020, } & \text { juga ditemukan }\end{array}$
keterbatasan-keterbatasan antara lain: kurangnya media konkrit; penggunaan metode ceramah melalui fasilitas voice note dalam aplikasi whatsapp dan membaca buku tanpa menggunakan variasi metode pembelajaran lainnya selama pembelajaran matematika peserta didik merasa kesulitan untuk memahami materi yang disampaikan oleh pendidik karena tidak dapat melihat pendidik secara langsung dalam menyampaikan mater; pembelajaran matematika menggunakan google classroom tidak dapat berdiskusi secara live chatting sehingga menyulitkan pendidik untuk mengakomodir pertanyaanpertanyaan yang muncul dari peserta didik di kolom komentar google classroom dan whatsapp group secara bersamaan; pendidik tidak dapat membuat variasi soal untuk matematika di dalam google form karena hanya dapat berupa pilihan ganda dan isian; pendidik tidak dapat memberi masukan kepada setiap peserta didik saat salah menjawab pertanyaan latihan di google form.

Selanjutnya, terdapat keterbatasan pembelajaran matematika lainnya yang didapatkan melalui wawancara dengan beberapa peserta didik pada tanggal 8 dan 9 November 2020. Keterbatasan-keterbatasan tersebut antara lain: pembelajaran matematika menggunakan whatsapp dan google classroom terasa membosankan bagi peserta didik; berdasarkan materi yang telah dipelajari peserta didik yaitu pecahan senilai, pembelajaran dianggap sulit dipahami tanpa menggunakan media konkrit pecahan senilai; peserta didik sulit untuk memahami materi matematika tentang pecahan senilai yang ada di buku hanya dengan bantuan fasilitas voice note dari aplikasi whatsapp.

Berdasarkan hasil observasi dan wawancara tersebut, peneliti menyimpulkan bahwa proses pembelajaran matematika di salah satu sekolah dasar negeri di Jakarta Selatan, khususnya kelas IV kurang optimal. Hal ini dapat menyulitkan pendidik saat memberikan materi pecahan senilai karena 
dibutuhkan usaha yang lebih untuk menggunakan dua media berbasis tekonologi sekaligus dalam waktu yang bersamaan. Selain itu peserta didik yang sulit memahami materi pembelajaran yang diajarkan tanpa menggunakan media konrit, menyebabkan nilai latihan maupun ujian matematika menjadi jelek. Hal ini sangat merugikan dan berpengaruh pada laporan nilai matematika peserta didik. Oleh karena pengaruh yang merugikan dari kurang optimalnya pembelajaran matematika di kelas IV terhadap laporan nilai matematika peserta didik, dibutuhkan suatu media berupa video yang dapat menampilkan penjelasan mengenai materi pecahan senilai secara konkrit, sehingga dapat membantu peserta didik dalam memahami materi pecahan senilai dalam matematika.

Dalam implementasinya, pecahan senilai digunakan dalam kehidupan seharihari. Salah satu contohnya adalah ketika peserta didik harus mampu menyamakan nilai suatu barang. Implementasi tersebut erat kaitannya dengan materi pecahan senilai dalam matematika. Oleh karena itu, dalam mempelajari pecahan senilai, dibutuhkan adanya sebuah terobosan pembelajaran berupa media konkrit untuk membantu peserta didik dalam menguasai materi, terlebih selama pembelajaran jarak jauh.

Pemilihan media yang digunakan perlu diperhatikan dengan matang agar dapat mempermudah penyampaian informasi yang akan diberikan kepada peserta didik. Hal ini juga harus disesuaikan dengan kondisi peserta didik, karakteristik materi yang akan diajarkan, dan fasilitas yang tersedia untuk digunakan. Salah satu media yang cocok untuk menjawab permasalahan-permasalahan yang telah dipaparkan adalah media e-earning berbasis Moodle.

Moodle merupakan salah satu aplikasi yang dikembangkan pertama kali oleh Martin Dougiamas pada Agustus 2002 dengan versi 1.0, dimana aplikasi moodle ini merupakan aplikasi open source yang paling terkenal diantara aplikasi e-learning yang lain, yaitu Atutor, Chamilo, Claroline, dan lainnya (Wicaksana, 2020). Selain itu, moodle termasuk dalam perangkat LMS (Learning
Management System) atau platform e-learning yang berupa perangkat lunak untuk membantu dalam menyampaikan materi pembelajaran melalui internet tanpa batasan ruang dan waktu, dimana penggunaannya sangat mudah dilakukan karena moodle menyediakan berbagai fitur e-learning yang mengizinkan penggunanya untuk memodifikasi sesuai dengan tujuan pembelajaran yang ingin dicapai (Rizal \& Walidain, 2019).

Moodle adalah aplikasi Course Management System (CMS) yang digunakan oleh universitas, perguruan tinggi, sekolah $\mathrm{K}$ 12, bisnis, dan bahkan instruktur individu untuk menambahkan teknologi web untuk kursus (Cole \& Foster, 2008). Adapun menurut Lackner (2015), moodle adalah aplikasi modular, dinamis dan memungkinkan kerja kolaboratif, komunikatif, dan kreatif dalam hal pembelajaran yang mengejar konstruktivisme. Moodle merupakan tempat belajar yang dinamis dengan menggunakan model dan memiliki oritentasi yang berdasarkan atas objek (Simanjuntak \& Puspitasari, 2020). Moodle menyediakan berbagai fasilitas yang dapat digunakan oleh pengguna (Gamage et al., 2019). Menurut Dvorak (2011), moodle merupakan aplikasi perangkat lunak berbasis web terbesar yang memungkinkan pendidik untuk membuat kursus berbasis internet.

Dari beberapa pendapat di atas dapat disintesiskan bahwa moodle merupakan salah satu aplikasi perangkat lunak berbasis web, serta open source yang digunakan di berbagai ranah, salah satunya ranah pendidikan, di mana moodle memungkinkan pembelajaran bersifat kolaboratif, komunikatif, dan kreaktif dengan menggunakan jaringan internet.

Kelebihan Moodle antara lain kemampuan membuat materi pembelajaran, kuis, forum, atau chat online, menyisipkan media gambar atau video atau flash, dan memiliki database yang dapat menyimpan data absensi peserta didik secara online, semua ini dalam satu paket e-learning (Fatmawati, 2019). Moodle dapat diterapkan sebagai sarana untuk meningkatkan hasil belajar peserta didik khususnya di Indonesia yang dilakukan secara bersamaan dengan kemampuan pendidik dalam menggunakan 
media berbasis internet dengan pendekatan moodle untuk menunjang proses pembelajaran sehingga hasil belajar siswa dan mutu pendidikan secara umum dapat ditingkatkan (Sari, Baedhowi, \& Indrawati, 2017). Dalam penggunaan Moodle sebagai salah satu media pembelajaran e-learning, moodle merupakan media pembelajaran yang sangat menjanjikan, dimana pendidik dapat mengatur dan mengelola kelas nya sendiri di dalam $e$ learning untuk membuat proses pembelajaran yang interaktif dan menarik sehingga dapat meningkatkan motivasi peserta didik dalam menerima pembelajaran (Jebari, Boussedra, \& Ettouhami, 2017).

Sebagai sebuah platform e-learning, moodle menyediakan fasilitas untuk dapat mengunggah file ektronik berupa buku elektronik, video pembelajaran, file power point, dan juga pengguna dapat memanfaatkan chat, forum diskusi, quiz dan survey dalam proses pembelajaran jarak jauh (Puspita Sari \& Setiawan, 2018). Moodle dipilih sebagai salah satu program e-learning yang dipakai di sekolah karena moodle menyediakan fasilitas canggih untuk menyesuaikan konteks serta mengelola ruang kelas digital (Panyajamorn et al., 2018).

Dari beberapa pendapat di atas dapat disintesiskan bahwa moodle memiliki manfaat dalam meningkatkan pendidikan di Indonesia melalui pembelajaran yang interaktif dan menarik dengan fasilitas yang disediakan oleh moodle sehingga memudahkan interaksi antar pengguna moodle dalam bertukar informasi saat proses pembelajaran tanpa dibatasi oleh ruang dan waktu.

Berdasarkan uraian di atas, penggunaan $e$-leaning berbasis moodle sangat diperlukan. Melalui e-learning berbasis moodle, peserta didik dapat lebih mudah mempelajari materi yang diajarkan, serta aktif dan mandiri. E-Learning berbasis moodle dapat membantu peserta didik dalam memaksimalkan proses pembelajaran secara daring. Namun, faktanya belum terdapat media pembelajaran e-learning berbasis moodle yang berfokus pada pembelajaran matematika materi pecahan senilai di kelas IV SD.
Dikarenakan belum terdapat media pembelajaran e-learning berbasis moodle yang berfokus pada pembelajaran matematika materi pecahan senilai di kelas IV SD, peneliti tertarik untuk membuat pengembangan media pembelajaran e-learning berbasis moodle. Perbedaan hasil produk peneliti dengan hasil penelitian sebelumnya yaitu, pada penelitian ini peneliti mengembangkan media pembelajaran e-learning berbasis moodle yang digunakan dalam menyampaikan materi berupa video penjelasan mata pelajaran matematika, khususnya mengenai pokok bahasan pecahan senilai yang sesuai dengan permasalahan pembelajaran untuk peserta didik di kelas IV semester ganjil. Selanjutnya, penjelasan materi dijelaskan oleh peneliti secara langsung, serta penjelasan akan dibuat lebih konkrit menggunakan gambar animasi yang ada dalam kehidupan sehari-hari peserta didik, agar pembelajaran tidak membosankan dan dapat membantu peserta didik dalam memahami materi pecahan senilai. Selain itu, peserta didik juga dapat mengakses fasilitas live chat untuk berkonsultasi atau bertanya mengenai materi kepada pendidik.

Pada penelitian yang akan peneliti kembangkan, fasilitas live chat dalam $e$ learning akan dibuat bersamaan dengan penyisipan video media pembelajaran, dimana fasilitas live chat akan muncul dalam bentuk desktop sehingga memudahkan peserta didik untuk membuka fasilitas live chat, kemudian peserta didik juga dapat menjawab quiz untuk mengukur kemampuan peserta didik terhadap materi yang dipelajari, serta pendidik dapat memberikan umpan balik pada jawabanjawaban yang dijawab oleh peserta didik di dalam quiz, dan mengamati aktivitas peserta didik secara real time di dalam e-learning moodle.

Penelitian ini berupaya untuk mengembangkan media pembelajaran $e$ learning berbasis Moodle pada materi pecahan senilai Kelas IV SD dengan harapan produk ini dapat mengatasi keterbatasan yang dialami peserta didik dan pendidik selama pembelajaran jarak jauh, terutama dalam proses pembelajaran matematika pokok bahasan pecahan senilai. 


\section{METODE PENELITIAN}

Pengembangan ini juga memiliki tujuan untuk menghasilkan sebuah media yang sudah teruji dan layak digunakan oleh pendidik sebagai media pembelajaran yang akan membantu peserta didik lebih mudah dalam memahami pembelajaran matematika materi pecahan senilai kelas IV SD dan dapat membuat peserta didik lebih antusias untuk mengikuti proses pembelajaran.

Metode penelitian yang digunakan adalah metode penelitian dan pengembangan atau research and development ( $\mathrm{R} \& \mathrm{D})$. Seels dan Richey mendefinisikan bahwa penelitian dan pengembangan merupakan suatu proses penerjemahan spesifikasi desain ke dalam bentuk fisik (Yaumi, 2018). Dalam penelitian dan pengembangan ini, peneliti menggunakan model ASSURE yang terdiri dari 6 tahapan, yaitu (1) analyze learner; (2) state objectives; (3) select method, media, and material; (4) utilize media and material; (5) require learner participation; and (6) evaluate and revise (Heinich, Molenda, \& Russell, 1990).

Teknik pengumpulan data yang digunakan dalam pengembangan media pembelajaran e-learning berbasis moodle adalah observasi, wawancara, kuesioner, dan dokumentasi. Observasi dan wawancara digunakan untuk mengumpulkan data terkait analisis kebutuhan guru dan peserta didik. Sedangkan wawancara, kuesioner, dan dokumentasi digunakan untuk mengumpulkan data terkait kelayakan produk. Teknik analisis data yang digunakan statistik deskriptif kuantitatif kemudian dikonversikan ke data kualitatif dengan menggunakan skala likert untuk mengetahui kualitas produk.

Teknik analisis data yang digunakan adalah statistik deskriptif dan deskriptif kualitatif. Teknik analisis data statistik deskriptif digunakan untuk mengolah data kuesioner dan teknik analisis data deskriptif kualitatif untuk mengolah data wawancara. Teknik analisis data yang digunakan menggunakan model analisis interaktif dari Miles dan Huberman yang terdiri dari data condensation, data display, dan conclusion. Teknik pengukuran yang digunakan dalam pengumpulan data adalah skala Likert. Untuk keperluan analisis kuantitatif, jawaban diberi skor yang telah ditetapkan yaitu, satu, dua, tiga, dan empat.

Tabel 1. Kategori Skor Skala Likert

\begin{tabular}{ccc}
\hline No & Kategori & Skor \\
\hline 1 & Sangat Baik & 4 \\
2 & Baik & 3 \\
3 & Kurang & 2 \\
5 & Sangat Kurang & 1
\end{tabular}

Sumber: (Sugiyono, 2017)

Presentase kelayakan dihitung dengan menggunakan rumus:

$$
\frac{\text { Jumlah Skor Total Jawaban }}{\text { Jumlah Skor Total Maksimum Tiap Indikator }} \times 100 \%
$$

Jika perhitungan presentase kelayakan sudah didapatkan maka tahapan yang harus dilakukan setelahnya adalah penunjukan predikat kualitas dari produk yang dibuat berdasarkan skala pengukuran Rating Scale. Skala penunjukan Rating Scale adalah pengubahan data kuantitatif menjadi kualitatif. Berikut tabel Rating Scale yang digunakan sebagai penafsiran kelayakan produk:

Tabel 2. Kategori Kelayakan Berdasarkan Rating Scale

\begin{tabular}{ccc}
\hline No & Skor dalam Persen \% & $\begin{array}{c}\text { Kategori } \\
\text { Kelayakan }\end{array}$ \\
\hline 1 & $0-25$ & Sangat Tidak \\
Layak \\
2 & $26-50$ & Kurang Layak \\
3 & $51-75$ & Cukup Layak \\
5 & $76-100$ & Sangat Layak \\
\hline
\end{tabular}

Sumber: (Sugiyono, 2016)

\section{HASIL DAN PEMBAHASAN}

Dalam penelitian dan pengembangan Media Pembelajaran E-Learning Berbasis Moodle, peneliti menggunakan model ASSURE yang terdiri dari 5 tahapan. Berikut ini hasil pengembangan yang dilakukan peneliti di setiap tahap:

\section{Analyze Learners}

a. Analisis Kebutuhan Guru

Berdasarkan wawancara dengan guru kelas IV SD Negeri di Jakarta Selatan, peserta didik kesulitan dalam memahami konsep pecahan senilai. Kesalahan yang sering ditemukan adalah anggapan peserta didik bahwa $\mathrm{a} / \mathrm{b}$ tidak sama nilainya dengan 
ma/mb.. Hal ini dikarenakan peserta didik hanya melihat dari perbedaan angka yang terdapat pada pembilang dan penyebut pada pecahan tersebut dan kurangnya pemahaman konsep pecahan senilai dari media konkrit, sehingga menganggap kedua pecahan tidak senilai.

Metode pembelajaran yang digunakan oleh pendidik dalam mengajarkan materi pecahan senilai menggunakan metode jarak jauh serta melakukan tindakan interpersonal (khusus) untuk menanyakan bagian yang dirasa sulit dipahami oleh perserta didik mengenai materi yang dipelajari. Namun hal tersebut kurang efektif dan membutuhkan waktu lebih lama.

Media pembelajaran yang digunakan selama proses pembelajaran adalah Google Classroom, Whatsapp Group, Video Youtube, dan buku penunjang. Menurut pendidik, media yang digunakan oleh pendidik belum mengkonkritkan materi yang diajarkan di kelas, video pembelajaran yang diperoleh dari youtube belum didesain khusus untuk pembelajaran, peserta didik merasa kesulitan karena tidak dapat melihat pendidik menjelaskan materi secara langsung, pendidik kesulitan dalam mengakomodir pertanyaan-pertanyaan dari peserta didik di kolom komentar google classroom dan whatsapp group secara bersamaan, tidak dapat membuat variasi soal untuk matematika di dalam google form karena hanya dapat berupa pilihan ganda dan isian, serta tidak dapat memberi masukan kepada peserta didik saat salah menjawab pertanyaan latihan di google form. Berdasarkan pendapat guru, diketahui bahwa media yang digunakan tidak dalam satu paket untuk pembelajaran jarak jauh, sehingga menyulitkan guru untuk menggunakan beberapa media sekaligus untuk peserta didik di dalam waktu yang bersamaan,

b. Analisis Kebutuhan Peserta Didik

Peserta didik yang berada di kelas IV SD berada pada rentang usia 7-12 tahun berada dalam tahapan operasional konkrit, dimana peserta didik sudah memiliki kemampuan dalam berpikir secara logis, namun hanya dengan benda-benda yang bersifat konkrit. Media pembelajaran yang belum didesain khusus secara konkrit untuk mempelajari matematika yang merupakan ilmu abstrak dirasa kesulitan oleh peserta didik.

Peserta didik di kelas IV di salah satu di Jakarta Selatan mengalami kesulitan dalam memahami materi pecahan senilai dalam pembelajaran matematika yang ada di Kurikulum 2013 semester 1. Berdasarkan hasil wawancara menunjukkan peserta didik tidak menguasai konsep pecahan senilai dan peserta didik juga kesulitan saat memberikan contoh mengenai pecahan senilai.

Berdasarkan hasil observasi dan wawancara, media pembelajaran yang digunakan saat pembelajaran matematika materi pecahan senilai tidak konkrit dan membosankan bagi peserta didik. Menurut peserta didik, video pembelajaran dari Youtube yang diberikan oleh guru di Google Classroom hanya berupa pengerjaan angka-angka, tidak ada gambar konkrit yang didesain khusus untuk membantu peserta didik dalam memahami materi. Peserta didik juga merasa bosan menggunakan media Google Classroom dan Whatsapp Group. Adapun penjelasan materi yang ada di buku cetak menggunakan fasilitas voice note dari aplikasi Whatsapp oleh pendidik, menyulitkan peserta didik dalam membayangkan materi yang diajarkan karena peserta didik harus berimajinasi sendiri tanpa bantuan media konkrit.

\section{State Objectives (Menyatakan Standar dan Tujuan)}

Standard dan tujuan pengembangan pembelajaran ini mengadopsi pembelajaran matematika materi pecahan senilai, kurikulum 2013 di mana kompetensi inti, kompetensi dasar, dan indikator berada pada Bab 1 materi pecahan senilai di buku "Senang Belajar Matematika SD/MI Kelas IV".

\section{Select Method, Media, and Materials}

Media pembelajaran yang dikembangkan pada penelitian ini adalah media pembelajaran e-learning berbasis moodle. Media ini berupa website di mana 
peserta didik akan dapat berkunjung ke dalam ruang kelas digital menggunakan jaringan internet dan sebuah link belajarpecahansenilai.site/moodle kemudian untuk masuk ke dalam ruang belajar, peserta didik menggunakan username dan password. Di dalam website ini, terdapat video pembelajaran yang sudah dilakukan embedded system dari aplikasi youtube, sehingga video pembelajaran dapat diputar di dalam moodle.

Video ini didesain secara khusus untuk menjelaskan materi pecahan senilai secara konkrit. Selain video pembelajaran, di dalam moodle terdapat juga fasilitas live chat untuk berkonsultasi antara pendidik dan peserta didik mengenai materi yang diajarkan, quiz sebagai latihan peserta didik setelah mempelajari materi yang disertai dengan feedback, dan absen secara online dimana pendidik dapat memantau aktivitas pendidik secara real time di dalam moodle.

Metode yang digunakan oleh peneliti dalam pengembangan media pembelajaran $e$ learning berbasis moodle ini adalah metode pembelajaran jarak jauh dan menggunakan teknologi informasi dan komunikasi untuk kelas IV Sekolah Dasar yang dalam penggunaannya menggunakan smartphone atau laptop untuk mengakses halaman website.

Materi yang digunakan oleh peneliti untuk pengembangan media pembelajaran elearning berbasis moodle adalah materi pecahan senilai yang ada dalam pembelajaran matematika kelas IV Sekolah Dasar, kurikulum 2013. Kompetensi Dasar yang digunakan adalah KD 3.1 Menjelaskan pecahan-pecahan senilai dengan gambar dan model konkrit dan KD 4.1 Mengidentifikasi pecahan-pecahan senilai dengan gambar dan model konkrit.

\section{Utilize Media and Materials}

Pengembangan media pembelajaran $e$ learning berbasis moodle untuk kelas IV Sekolah Dasar dibagi menjadi beberapa tahap, yaitu:

a. Menentukan Garis Besar Isi Program Media (GBIPM).

GBIPM (Garis Besar Isi Program
Media) berisi identifikasi program yang dijadikan sebagai petunjuk dan pedoman bagi penulis naskah dalam pembuatan program media. Kompetensi dasar dan Indikator yang ada pada Kurikulum 2013 dijadikan acuan sebagai pembuatan GBIPM.

b. Membuat Naskah atau Skenario Video Pembelajaran.

Pembuatan naskah atau skenario diperlukan untuk mengetahui konsep pembelajaran matematika materi pecahan senilai yang akan dibuat untuk video pembelajaran. Video pembelajaran di dalam e-learning ini dibagi menjadi tiga video, yaitu video 1: mengenal pecahan, video 2: pecahan senilai, video 3 , menyederhanakan dan membandingkan pecahan. Hal ini membuat peneliti menyusun total tiga skenario, untuk masing-masing video pembelajaran menggunakan satu skenario.

c. Pengambilan Gambar untuk Video Pembelajaran.

Pengambilan gambar untuk video pembelajaran menggunakan smartphone Realme C12 dengan resolusi $720 \times 1560$ pixels dan dengan kamera belakang 12 MP.

d. Editing dan Compotioning untuk Video Pembelajaran.

Untuk editing dan compositioning, peneliti menghasilkan video pembelajaran menggunakan resolusi PAL 720p dengan Line $1280 \mathrm{x}$ 720. Proses editing dan compositioning untuk video pembelajaran menggunakan aplikasi pembantu, yaitu Filmora. Di dalam video pembelajaran, peneliti menyisipkan backsound atau latar lagu untuk menambah suasana ceria di dalam video pembelajaran. Backsound yang digunakan berjudul "Happy Vlog No Copyright Music By Aden”. Besar volume yang digunakan untuk backsound adalah sebesar -28 dp, serta untuk suara guru adalah $100 \%$. Hal ini agar suara dari guru tidak tertutup oleh backsound. Video yang dihasilkan untuk video 1 berdurasi 6.54 menit, video 2 berdurasi 12.03 menit, dan video 3 berdurasi 7.28 menit. 
e. Membuat Website untuk E-learning Moodle.

Untuk membangun sebuah website e-learning berbasis moodle, peneliti menggunakan jasa hosting serta domain dari Hostinger agar website yang peneliti buat dapat diakses oleh peserta didik. Setelah melakukan penyewaan hosting, peneliti baru dapat membuat e-learning moodle.

Langkah-langkah yang dilakukan peneliti untuk membuat e-learning moodle adalah (1) Melakukan login ke akun Hostinger menggunakan email dan password yang sudah peneliti daftarkan sebelumnya, (2) Masuk ke halaman hPanel untuk melakukan auto installer moodle di mesin pencarian yang disediakan oleh Hostinger, (3) Setelah menemukan Moodle installer, klik Moodle installer, (4) Isi informasi-informasi atau data yang dibutuhkan untuk membangun website, (5) Klik 'install' dan website akan otomatis terbuat, (6) Untuk mengunjungi situs web Moodle yang sudah terbuat, cukup klik pada URL yang disediakan dan masuk menggunakan username dan password admin yang sudah terdaftar sebelumnya.

f. Membuat Desain untuk Website.

Peneliti menggunakan tema E-Guru sebagai tema yang digunakan di dalam elearning moodle, di mana tema ini sudah peneliti modifikasi. Untuk mendapatkan tema E-Guru, langkah-langkah yang harus dilakukan adalah: (1) Mengunduh tema EGuru dari website moodle.org https://moodle.org/plugins/browse.php?list =category\&id=3 (2) Setelah mengunduh tema, maka file yang diunduh akan berbentuk zip, (3) Buka e-learning moodle yang sudah kita buat dan masukan username serta password, maka kita akan masuk ke dalam e-learning moodle, (4) Setelah masuk, pilih site administration, plugins, dan install plugins, (5) Klik Install Plugins From the Moodle Plugins Directory, (6) Pada bagian install plugin from ZIP file, seret dan letakkan file zip EGuru yang sudah kita unduh sebelumnya, kemudian klik Install Plugin from the Zip File, (7) Selanjutnya, akan ada pesan konfrimasi, lalu klik tombol continue, dan upgrade database now (8) Jika sudah ada pesan "success", lanjutkan untuk klik tombol continue, (9) Kemudian sunting tema yang terdiri dari logo, slide, dll sesuai dengan apa yang ingin dimodifikasi, jika sudah dilakukan semua, klik tombol save changes.

Ilustrasi untuk desain website menggunakan gambar kartun untuk mempermudah peserta didik dalam memahami materi, serta perpaduan warna untuk desain website disesuaikan dengan perkembangan peserta didik yang menyukai warna terang. Di dalam website yang peneliti kembangkan ini, didominasi oleh warna ungu. Ilustrasi untuk desain website dibuat dengan bantuan aplikasi pendukung yaitu Adobe Ilustrator.

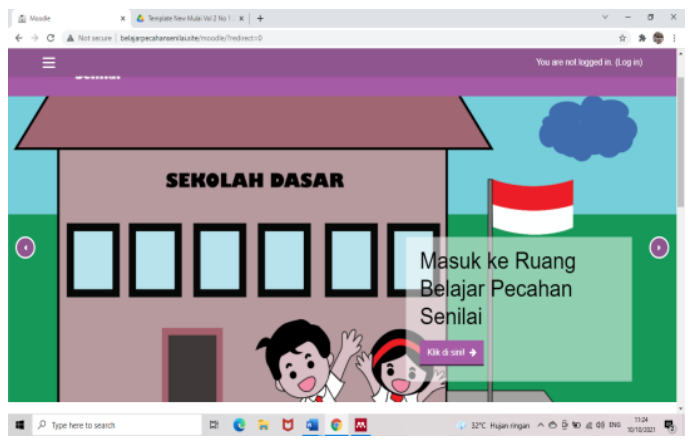

Gambar 1: Gambar Tampilan Halaman Utama Media Pembelajaran E-Learning Berbasis Moodle Pada Matematika Materi Pecahan Senilai (Sumber: Dokumentasi Penulis)

g. Membuat Kursus atau Kelas di dalam ELearning Moodle.

Peneliti melakukan beberapa langkah-langkah untuk membangun kursus atau kelas di dalam moodle, yaitu (1) Klik menu site administration, (2) Klik course dan pilih manage courses and categories, (3) Klik create new course, (4) Kemudian isi informasi - informasi atau data yang akan digunakan untuk membuat kelas, (5) Jika sudah selesai, klik save and display, maka kelas akan otomatis muncul di dalam halaman e-learning moodle.

h. Melakukan Embedded System untuk Video Pembelajaran di dalam Moodle.

Dalam melakukan embedded system untuk video pembelajaran di dalam 
moodle, terdapat beberapa langkah yang harus dilakukan yaitu: (1) Pilih kursus atau kelas yang ingin difasilitasi embedded system, (2) Klik tombol turn editing on, (3) Pilih add an activity or resource, (4) Klik lesson, (4) Pada name, ketik judul video pembelajaran yang ingin dibuat, (5) Pada kolom description sisipkan link video yang ingin di-embedded, kemudian klik save and back to course, maka video pembelajaran akan otomatis terunggah di dalam moodle.

i. Membuat Fitur Live Chat di dalam ELearning Moodle.

Dalam membuat fitur live chat di dalam e-learning moodle, terdapat beberapa langkah yang harus dilakukan, yaitu: (1) Pilih kursus atau kelas yang ingin difasilitasi live chat, (2) Klik tombol turn editing on, pilih add an activity or resource, (3) Klik chat, maka desktop live chat akan muncul secara otomatis di dalam kelas yang dibuat.

j. Membuat Fitur Quiz di dalam E-Learning Moodle.

Dalam membuat fitur quiz di dalam e-learning moodle, terdapat beberapa langkah yang harus dilakukan, yaitu: (1) Pilih kursus atau kelas yang ingin difasilitasi quiz, (2) Klik tombol turn editing on, pilih add an activity or resource, (3) Klik quiz, maka kita akan diarahkan untuk memilih variasi soal-soal yang akan kita buat untuk quiz kita di dalam kelas. Variasi soal yang peneliti buat untuk pengembangan ini adalah multiple choices, short answer, drag and drop onto image, true / false, dan matching.

\section{Require Learner Participation}

Dalam tahap ini, peneliti melakukan uji coba media. Uji coba media dilakukan oleh peneliti melalui dua tahap, yaitu uji coba ahli atau expert review dan uji coba terhadap peserta didik.

\section{a. Tahap Expert Review}

Uji coba ahli melibatkan tiga orang ahli, yaitu 1 ahli materi matematika (Dosen Matematika), 1 ahli media (Dosen
Teknologi Pendidikan), dan 1 ahli bahasa (Dosen Bahasa Indonesia). Berikut adalah paparan data hasil penilaian ahli materi, media, dan bahasa terhadap produk media pembelajaran e-learning berbasis moodle pada matematika materi pecahan senilai kelas IV SD yang telah dibuat oleh peneliti.

Tabel 3. Tabel Hasil Rekapitulasi Evaluasi Formatif Ahli (Expert Review)

\begin{tabular}{cccc}
\hline No & Responden & $\begin{array}{c}\text { Skor yang } \\
\text { didapat }\end{array}$ & Rerata \\
\hline 1 & Ahli Materi & 54 & $90 \%$ \\
2 & Ahli Media & 59 & $86,7 \%$ \\
3 & Ahli Bahasa & 37 & $84,9 \%$ \\
& Rata-Rata Keseluruhan & $87,2 \%$ \\
\hline
\end{tabular}

Sumber: Hasil Pengolahan Skala Likert

Dari hasil evaluasi di atas, rata-rata keseluruhan nilai yang diperoleh dari para ahli adalah $\mathbf{8 7 , 2 \%}$ yang artinya sangat layak.

\section{b. Tahap One to One Tryouts}

Tahap uji coba one to one tryouts dilaksanakan untuk melakukan penilaian produk berdasarkan hasil wawancara dengan tiga orang peserta didik. Responden pada tahap one to one tryouts adalah peserta didik kelas IV SDN Ragunan 01. Ketiga peserta didik ini dipilih oleh guru kelas IV berdasarkan tingkat kemampuan peserta didik, sehingga bersifat heterogen. Berikut hasil penilaian tiga peserta didik terhadap produk media pembelajaran e-learning berbasis moodle pada matematika materi pecahan senilai kelas IV SD melalui wawancara:

1) Kejelasan Gambar

Gambar pada video pembelajaran bagus, menarik, unik, jelas, kreatif dan lucu karena gambar menyerupai kartun sehingga peserta didik lebih mudah dalam memahami materi. Untuk gambar tombol desktop pada live chat terlihat dengan jelas serta gambar yang disajikan pada kuis juga terlihat dengan jelas

\section{2) Kekonkritan Gambar}

Gambar pada video pembelajaran sudah menggunakan benda konkrit yang ada di sekitar peserta didik dan terlihat seperti aslinya.

3) Penggunaan Kalimat 
Kalimat yang digunakan di dalam $e$ learning moodle mudah dimengerti dan tulisan atau huruf mudah dibaca.

\section{4) Kejernihan Audio}

Peserta didik menyatakan bahwa mereka menyukai latar lagu, iringan musik atau backsound pada video pembelajaran. Suara dalam video pembelajaran juga terdengar sangat jelas.

\section{5) Interaksi dengan Video}

Ketiga peserta didik menyatakan bahwa mereka tidak merasa kesulitan dalam memahami materi yang disajikan dalam video pembelajaran dan merasa mudah untuk memahaminya. Mereka dapat dengan mudah menemukan informasi dalam video pembelajaran.

\section{6) Ketertarikan Peserta Didik}

Ketiga peserta didik menyatakan bahwa mereka tertarik dan mau belajar menggunakan media pembelajaran $e$ learning berbasis moodle untuk mata pelajaran matematika materi pecahan senilai karena medianya bagus.

\section{7) Kemudahan Penggunaan Media}

Ketiga peserta didik menyatakan bahwa media pembelajaran e-learning berbasis moodle mudah digunakan untuk belajar pecahan senilai dan mereka tidak merasa kesulitan dalam mengoperasikan menu-menu yang ada di dalam e-learning moodle.

\section{8) Live Chat}

Ketiga peserta didik menyatakan bahwa fasilitas live chat yang ada di dalam media pembelajaran e-learning berbasis moodle mudah digunakan untuk berkonsultasi mengenai materi kepada peserta didik.

\section{9) Kuis}

Ketiga peserta didik menyatakan bahwa fasilitas kuis yang ada di dalam media pembelajaran e-learning berbasis moodle, yang digunakan peserta didik untuk latihan mengenai materi pecahan senilai mudah untuk digunakan dan tidak merasa kesulitan dalam pengoperasiannya.
Selain itu salah satu peserta didik menyatakan bahwa kuis yang ada di dalam e-learning seru.

Pada tahap ini tidak didapatkan perbaikan atau saran dari peserta didik. Adapun dokumentasi yang dilakukan pada tahap uji coba one to one tryouts sebagai berikut:

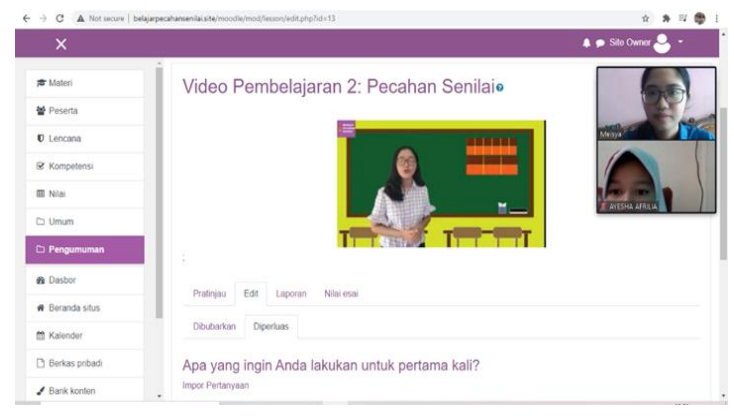

Gambar 2. Gambar: Tahap One to One Tryouts (Sumber: Dokumentasi Penulis)

\section{c. Tahap Field Trials}

Tahapan terakhir dalam uji coba produk adalah tahap field trial. Tahap ini dilakukan bersama 15 peserta didik kelas IV SDN Ragunan 01 yang tidak terlibat dalam tahap one to one tryouts. Kegiatan yang dilakukan dalam tahap ini adalah penerapan penggunaan media pembelajaran e-learning berbasis moodle kepada peserta didik dan penilaian formatif. Berikut ini adalah hasil rekapitulasi pada tahap field trials:

Tabel 4. Tabel Hasil Rekapitulasi pada tahap field trials.

\begin{tabular}{ccc}
\hline No & Responden & Rerata \\
\hline 1 & DAA & $93,3 \%$ \\
2 & NAP & $100 \%$ \\
3 & ZPK & $93,3 \%$ \\
4 & FI & $100 \%$ \\
5 & SQP & $100 \%$ \\
6 & NNR & $100 \%$ \\
7 & KA & $93,3 \%$ \\
8 & AAA & $100 \%$ \\
9 & DYN & $100 \%$ \\
10 & IKJ & $100 \%$ \\
11 & HR & $100 \%$ \\
12 & ARA & $86,6 \%$ \\
13 & NA & $100 \%$ \\
14 & MZA & $86,6 \%$ \\
15 & NK & $93,3 \%$ \\
Rerata Keseluruhan & $\mathbf{9 6 , 4 2 \%}$ \\
\multicolumn{2}{r}{} \\
\hline
\end{tabular}

Sumber: Hasil Pengolahan

Berdasarkan hasil rekapitulasi di atas, maka didapatkan nilai rata-rata dari 
tahap ini adalah sebesar $\mathbf{9 6 , 4 2 \%}$ yang artinya sangat layak. Pada tahap ini tidak didapatkan perbaikan dan saran dari peserta didik. Adapun dokumentasi yang dilakukan pada tahap field trial sebagai berikut:

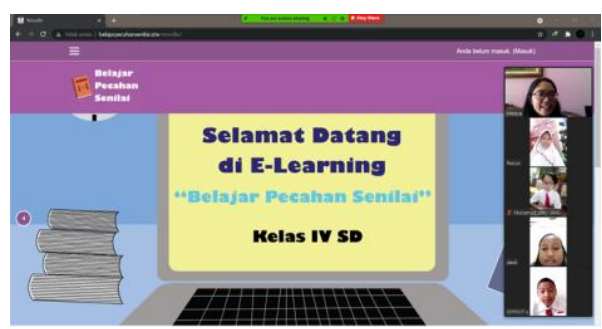

Gambar 3: Gambar Tahap Field Trials

(Sumber: Dokumentasi Penulis).

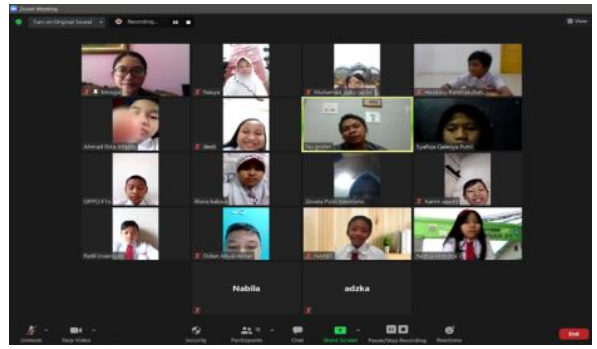

Gambar 4: Gambar Tahap Field Trials

(Sumber: Dokumentasi Penulis)

\section{Evaluate and Revise}

Pada tahap evaluate and revise, peneliti mendapatkan saran dan masukkan dari para ahli terhadap media pembelajaran e-learning berbasis moodle. Setelah itu peneliti memperbaikinya sesuai dengan saran dari para ahli. Dalam tahap one to one tryouts dan field trials, peneliti tidak mendapatkan saran ataupun masukkan dari peserta didik terhadap produk media pembelajaran e-learning berbasis moodle, sehingga media pembelajaran e-learning berbasis moodle sampai pada tahap akhir.

Dalam penelitian ini, analisis data yang digunakan oleh peneliti adalah model Miles dan Huberman. Hal yang dilakukan oleh peneliti adalah data condensation, di mana dalam tahap ini peneliti mengkategorikan data dari hasil pengumpulan data yang diperoleh oleh peneliti, kemudian tahap selanjutnya adalah data display, di mana data yang telah dikumpulkan oleh peneliti disajikan dalam sebuah tabel, serta conclusion drawing, di mana dalam tahap ini terdapat penarikan kesimpulan dari dua tahap sebelumnya.
Berikut adalah tahap analisis data menggunakan model Miles dan Huberman:

\section{Data Condensation}

a. Pemahaman Peserta Didik Mengenai Konsep Materi

Berdasarkan hasil analisis kebutuhan, ditemukan bahwa terdapat kesalahan konsep matematika mengenai materi pecahan senilai pada peserta didik kelas IV di salah satu SD Negeri di Jakarta Selatan.

b. Peran Guru

Peran guru yang dilakukan berdasarkan hasil wawancara yang dilakukan oleh peneliti kepada salah satu guru kelas IV di SD Negeri di Jakarta Selatan adalah melakukan tindakan khusus atau interpersonal kepada peserta didik yang kesulitan dalam memahami konsep pecahan senilai tanpa menggunakan media penunjang lainnya yang belum menkonkritkan materi. Selain itu, sangat sulit menggunakan beberapa media sekaligus untuk mengajarkan konsep pecahan senilai, serta hal tersebut kurang efektif dan membutuhkan waktu lebih lama.

c. Hasil Produk yang Dikembangkan

Berdasarkan

permasalahanpermasalahan yang ditemukan dalam pembelajaran matematika materi pecahan senilai kelas IV SD, peneliti mengatasi permasalahan-permasalahan tersebut dengan mengembangkan media pembelajaran e-learning berbasis moodle pada matematika materi pecahan senilai kelas IV SD. Produk yang peneliti kembangkan ini didesain secara khusus dan disesuaikan dengan karakteristik peserta didik guna membantu peserta didik lebih mudah dalam menguasai materi atau dalam memahami konsep pecahan senilai pada matematika. Media pembelajaran yang dikembangkan merupakan media yang cocok untuk menjawab kebutuhankebutuhan yang diperoleh oleh peneliti di awal. Semua hal tersebut peneliti kembangkan dalam satu paket e-learning. Media pembelajaran e-learning berbasis moodle ini dapat diakses oleh peserta didik 
dengan laptop atau smartphone. Peserta didik akan masuk ke dalam ruang kelas digital melalui sebuah link.

\section{Data Display}

Data display yang disajikan oleh peneliti adalah dalam bentuk tabel yang terdiri dari tabel pemahaman peserta didik mengenai konsep materi, peran guru, dan hasil produk yang dikembangkan.

\section{Conclusion Drawing}

Kesimpulan berdasarkan hasil penelitian yang telah dilakukan oleh peneliti didapatkan bahwa pembelajaran matematika materi pecahan senilai kelas IV di salah satu SD Negeri di Jakarta Selatan masih kurang optimal, hal ini dibuktikan dengan kesulitan peserta didik dalam memahami konsep pecahan senilai dan kesalahan pemahaman tentang konsep pecahan senilai yang dimiliki oleh peserta didik kelas IV pada saat tahap analisis kebutuhan. Peserta didik masih salah dalam menyebutkan konsep pecahan senilai, begitu juga dengan kesalahan yang sering ditemukan pada peserta didik oleh guru. Hal tersebut dikarenakan faktor kurangnya media pembelajaran yang dapat menunjang pembelajaran, khususnya media pembelajaran konkrit untuk materi pecahan senilai yang sesuai dengan perkembangan peserta didik. Hal ini didukung dengan penelitian yang terdahulu yang dilakukan oleh Aisyah Puspa Pertiwi bahwa sering terjadi kesalahan pemahaman konsep pada siswa kelas IV SD untuk materi pecahan senilai (Pertiwi, 2017).

Berdasarkan pada hal itu, peneliti mengembangkan produk media pembelajaran e-learning berbasis moodle yang di dalamnya terdapat video pembelajaran yang sudah disesuaikan dengan perkembangan peserta didik, di mana video pembelajaran tersebut dibuat secara konkrit melalui gambar-gambar ilustrasi yang ditampilkan dan sesuai dengan kehidupan sehari-hari peserta didik, sehingga peserta didik tidak perlu berimajinasi saat mempelajari pecahan senilai dalam ilmu matematika yang abstrak dan membantu peserta didik memahami konsep materi pecahan senilai. Hal ini didukung oleh penelitian sebelumnya bahwa menurut Piaget peserta didik kelas IV SD berada dalam tahap operasional konkrit di mana mereka dapat memahami suatu hal, namun hanya pada hal-hal yang bersifat konkrit atau real (Juwantara, 2019).

Selain itu, terdapat pula kuis yang dapat digunakan sebagai latihan peserta didik, live chat yang dapat digunakan untuk berkonsultasi kepada pendidik di dalam e-learning, dan absen di mana guru dapat memantau aktivitas peserta didik secara real time. Hal ini didukung dengan penelitian yang dilakukan oleh Petrus Tumijan dan Agung Purwanto bahwa proses pembelajaran menggunakan media e-learning moodle dengan pengembangan materi yang dikelola serta disesuaikan dengan karakteristik peserta didik dapat memberikan pengaruh yang baik bagi proses pembelajaran peserta didik (Tumijan \& Purwanto, 2018).

\section{SIMPULAN DAN SARAN}

Penelitian dan pengembangan ini menghasilkan produk Media Pembelajaran $E$ Learning berbasis Moodle pada Matematika Materi Pecahan Senilai Kelas IV SD. Model pengembangan yang dilakukan oleh peneliti adalah model pengembangan ASSURE dan mengadaptasi proses evaluasi formatif dari Dick and Carey. Media pembelajaran ini mengacu pada materi pecahan senilai yang ada di dalam pembelajaran matematika kurikulum 2013. Materi pecahan senilai yang ada di dalam media ini dikemas dalam bentuk video pembelajaran, gambar, dan kuis yang sudah didesain secara khusus dan konkrit sesuai dengan perkembangan peserta didik kelas IV SD.

Hasil uji coba Pengembangan Media Pembelajaran E-Learning Berbasis Moodle dari para ahli diperoleh skor $90 \%$ untuk ahli materi, 86,7\% untuk ahli media, dan $84,9 \%$ untuk ahli bahasa, sehingga produk memperoleh rerata skor sebesar $87,2 \%$ yang berarti sangat layak dan dapat digunakan pada tahap selanjutnya dengan beberapa perbaikan pada produk. Pada tahap uji coba one to one tryouts ketiga anak mau menggunakan media 
pembelajaran e-learning berbasis moodle dan peneliti tidak mendapat perbaikan pada produk. Pada tahap field trials, media pembelajaran e-learning berbasis moodle yang dikembangkan memperoleh rata-rata skor sebesar $96,42 \%$ yang artinya sangat layak.

Media pembelajaran e-learning berbasis moodle diharapkan dapat dijadikan sebagai referensi dan inspirasi dalam pembuatan media pembelajaran, khususnya media pembelajaran e-learning di sekolah dasar. Guru disarankan menggunakan media pembelajaran ini sebagai referensi dalam penggunaan media pembelajaran saat mengajarkan materi pecahan senilai. Peserta didik disarankan untuk memanfaatkan media pembelajaran yang ada sebagai sarana untuk mengembangkan diri secara positif dan media pembelajaran e-learning berbasis moodle ini diharapkan dapat dijadikan referensi dalam pengembangan media pembelajaran pada proses penelitian selanjutnya yang berhubungan dengan penelitian dan pengembangan media pembelajaran $e$ learning berbasis moodle, sehingga tercipta media pembelajaran yang kreatif dan inovatif.

\section{DAFTAR PUSTAKA}

Adnan, E., Juriana, Lestari, F., \& Novianti, R. (2016). Perkembangan Peserta Didik. Jakarta: Universitas Negeri Jakarta.

Anonim. (2020). Surat Edaran Nomor 4 Tahun 2020 Tentang Pelaksanaan Pendidikan dalam Masa Darurat Penyebaran CoronaVirus Disease (COVID-19). Kementerian Pendidikan dan Kebudayaan \& Indonesia. Google

Cole, J., \& Foster, H. (2008). Using Moodle: Teaching with The Popular Open Source Course Management System (2nd ed.; I. Kunkel, ed.). California: O'Reilly Media, Inc. Google Scholar

Dvorak, R. (2011). Moodle for Dummies. New Jersey: John Wiley \& Sons, Inc. Google Scholar.

Fatmawati, S. (2019). Efektivitas Forum Diskusi Pada E-Learning Berbasis Moodle Untuk Meningkatkan Partisipasi Belajar. Refleksi Edukatika :
Jurnal Ilmiah Kependidikan, 9(2). https://doi.org/10.24176/re.v9i2.3379

Gamage, S. H. P. W., Ayres, J. R., Behrend, M. B., \& Smith, E. J. (2019). Optimising Moodle quizzes for online assessments. International Journal of STEM Education, 6(1). https://doi.org/10.1186/s40594-0190181-4

Heinich, R., Molenda, M., \& Russell, J. D. (1990). Instructional Media and the New Technologies of Instruction (3rd ed.). New York: Macmillan. Google Scholar

Jebari, K., Boussedra, F., \& Ettouhami, A. (2017). Teaching "information systems management" with moodle. International Journal of Emerging Technologies in Learning, 12(4), 4-16. https://doi.org/10.3991/ijet.v12i04.6183

Juwantara, R. A. (2019). Analisis Teori Perkembangan Kognitif Piaget pada Tahap Anak Usia Operasional Konkret 7-12 Tahun dalam Pembelajaran Matematika. Al-Adzka: Jurnal Ilmiah Pendidikan Guru Madrasah Ibtidaiyah, 9(1), 27. https://doi.org/10.18592/aladzkapgmi.v 9i1.3011

Kimin, K. (2020). Meningkatkan Hasil Belajar Matematika Materi Pecahan Dengan Benda Kongkrit Pada Siswa Kelas II SDN Tuban Tahun Pelajaran 2017/2018. JISIP (Jurnal Ilmu Sosial Dan Pendidikan), 4(1). https://doi.org/10.36312/jisip.v4i1.1026

Kristiani, N., \& Prasetyo, Z. K. (2016). Keefektifan Pembelajaran Metematika Melalui Penggunaan Media Benda Konkret Pada Kelas V Sd Timuran. Jurnal Prima Edukasia, 4(2), 163. https://doi.org/10.21831/jpe.v4i2.7791

Lackner, E. (2015). Instructional Design for Blended Learning Settings: Moodle \& more. University of Graz Academy of New Media and Knowledge Transfer. Google

Muhammad, L. G. (2020). Transformasi Media Pembelajaran Pada Masa 
Pandemi COVID-19. Al-Hikmah ( Jurnal Studi Islam), 1(1), 92. http://ejournal.kopertais4.or.id/sasambo /index.php/alhikmah/article/view/3905

Simanjuntak, C. N. S., \& Puspasari, D. (2020). Pemanfaatan Media E-Learning Moodle Untuk Menunjang Pembelajaran Mahasiswa di Fakultas Manajemen dan Bisnis Universitas Ciputra. Jurnal Pendidikan Administrasi Perkantoran (JPAP), 8(1), 169-179. https://journal.unesa.ac.id/index.php/jpa p/article/view/8238

Panyajamorn, T., Suanmali, S., Kohda, Y., Chongphaisal, P., \& Supnithi, T. (2018). Effectiveness of E-Learning Design in Thai Public Schools. Malaysian Journal of Learning and Instruction, 15(1), 1-34. https://eric.ed.gov/?id=EJ1185780

Pertiwi, A. P. (2017). Analisis Kesalahan Siswa Kelas IV SD dalam Menyelesaikan Soal Bilangan Pecahan Senilai dan Menyederhanakan Bilangan Pecahan. Faculty of Teaching and Education Science, School of Elementary's Teacher Education, Universitas Muhammadiyah Sidoarjo. http://eprints.umsida.ac.id/605/

Purnomo, B. (2018). Pemahaman Konsep Matematika Siswa Melalui Model Pembelajaran Air (Auditory , Intellectualy, Repetition) Dan Model Pembelajaran Course Review Horay Pada Siswa Kelas Xi Ipa Sma Budi Utomo Jombang. Soulmath, 6(1), 1. https://doi.org/10.25139/sm.v6i1.376

Puspita Sari, A., \& Setiawan, A. (2018). The Development of Internet-Based Economic Learning Media using Moodle Approach. International Journal of Active Learning, 3(2), 100 109. Retrieved from http://journal.unnes.ac.id/nju/index.php/ ijal

Rizal, S., \& Walidain, B. (2019). Pembuatan Media Pembelajaran E-Learning Berbasis Moodle Pada Matakuliah Pengantar Aplikasi Komputer
Universitas Serambi Mekkah. JURNAL ILMIAH DIDAKTIKA: Media Ilmiah Pendidikan Dan Pengajaran, 19(2), 178. https://doi.org/10.22373/jid.v19i2.5032

Sari, A., Baedhowi, P., \& Indrawati, D. (2017). The Use of Learning Media with MOODLE Approach to Improve the Quality of Education: A Literature Study. 158(Ictte), 54-59. https://doi.org/10.2991/ictte-17.2017.33

Sugiyono. (2016). Metode Penelitian Kuantitatif, Kualitatif, dan $R \& D$. Bandung: Alfabeta. Google Scholar

Sugiyono. (2017). Metode Penelitian dan Pengembangan. Bandung: Alfabeta.Google Scholar

Syadiyah, H. A., \& Huda, S. (2020). Jurnal Inovasi Pendidikan Matematika Penerapan Model Pembelajaran Berbasis Masalah Menggunakan Geogebra Untuk Mengetahui Kemampuan Komunikasi Matematis Peserta Didik A . 67-76. http://journal.umg.ac.id/index.php/post ulat/article/view/1776

Tumijan, P., \& Purwanto, A. (2018). Pengembangan E-Learning Berbasis Moodle sebagai Upaya Inovatif untuk Meningkatkan Hasil Belajar IPA pada Materi Rangkaian Listrik Sederhana untuk Siswa Kelas VI SD PENABUR JAKARTA. PGSD, Universitas Pakuan, 1(1), 50-55. Retrieved from https://journal.unpak.ac.id/index.php/pr oceedings/article/view/1137/981

Wicaksana, E. (2020). Efektifitas Pembelajaran Menggunakan Moodle Terhadap Motivasi Dan Minat Bakat Peserta Didik Di Tengah Pandemi Covid -19. EduTeach: Jurnal Edukasi Dan Teknologi Pembelajaran, 1(2), 117-124. https://doi.org/10.37859/eduteach.v1i2. 1937

Yaumi, M. (2018). Media dan Teknologi Pembelajaran. Jakarta: Prenadamedia Group. Google Scholar 